TITLE:

\title{
Estimation of seed dispersal distance by the bonobo, Pan paniscus, in a tropical forest in Democratic Republic of Congo
}

\author{
$\operatorname{AUTHOR}(\mathrm{S})$ : \\ Tsuji, Yamato; Yangozene, Kumugo; Sakamaki, \\ Tetsuya
}

\section{CITATION:}

Tsuji, Yamato ... [et al]. Estimation of seed dispersal distance by the bonobo, Pan paniscus, in a tropical forest in Democratic Republic of Congo. Journal of Tropical Ecology 2009, 26(01): 115

ISSUE DATE:

2009-12

URL:

http://hdl.handle.net/2433/148240

\section{RIGHT:}

Copyright C Cambridge University Press 2009; この論文は著者最終稿で す。内容が印刷版と異なることがありますので、引用の際には出版社 版をご確認ご利用ください。This is the Accepted Author Manuscript. Please cite only the published version. 
Estimation of seed dispersal distance by the bonobo, Pan paniscus, in a tropical forest in Democratic Republic of Congo

Running title: Seed dispersal by bonobo

Yamato Tsuji $^{1 *}$, Kumugo Yangozene ${ }^{2} \&$ Tetsuya Sakamaki ${ }^{1}$

${ }^{1}$ Primate Research Institute, Kyoto University, Japan

${ }^{2}$ Research Center for Ecology and Forestry, Ministry of Scientific Research and

Technology, Democratic Republic of Congo

Key Words: Dialium zenkeri, Dialium pachyphyllum, estimation, independent bout method, Luo Scientific Reserve, seed dispersal, Wamba

*corresponding author: 
Great apes are considered to be important seed dispersers in palaeotropical habitats due to their large body size (this would be reflected in the amount of foods consumed) and large home ranges (Poulsen et al. 2001, Wrangham et al. 1994). Furthermore, the great apes might process seeds in a way that maintains their viability (Lambert 1999). Previous studies of seed dispersal by great apes have generally taken the form of lists of seeds found in their faeces (Voysey et al. 1999a, Wrangham et al. 1994), effects of passage through their guts on seed germination (Idani 1986, Wrangham et al. 1994), and effects of dispersal location on germination/seedling survival (Gross-Camp \& Kaplin 2005, Rogers et al. 1998, Voysey et al. 1999b). In contrast with the richness of reports about aspects of seeds after their dispersal, few studies have investigated the dispersal pattern of seeds. In this study, we report on the estimated distances of seed dispersal by the wild bonobo (Pan paniscus Schwartz), a species of great ape.

We observed a unit group of bonobos called E1 at Wamba $\left(0^{\circ} 11^{\prime} 8^{\prime \prime} \mathrm{N}, 22^{\circ} 37^{\prime} 58^{\prime \prime} \mathrm{E}\right)$, in the northern section of the Luo Scientific Reserve, Democratic Republic of Congo, from the end of November 2008 to the beginning of January 2009. The study site comprised primary forest, old secondary forest, young secondary forest, swamp forest and agricultural fields (Furuichi et al. 2008, Hashimoto et al. 1998). Annual rainfall was about $2900 \mathrm{~mm}$ (Furuichi et al. 2008). During the study, the E1 group was composed of 9 
adult ( $\geq 15$ y old) males, 7 adult females, 1 adolescent $(\leq 8-<15$ y) male, 2 adolescent females, 6 juveniles $(\leq 2-<8$ y), and 2 infants $(\leq 0-<2$ y), for a total of 27 animals. The E1 group has been habituated to humans since 1973 (Kano \& Mulavwa 1984); thus we could observe them at close distance (ca. $10 \mathrm{~m}$ ). We tried to locate parties of the E1 group from dawn to dusk, on $6 \mathrm{~d}$ of each week. During observation, we recorded the location of the group every 10 min using GPS equipment (Garmin GPS map 60CSx, Kansas, USA). We also recorded the activity of visible bonobos by scan sampling every $10 \mathrm{~min}$. Activity was categorized as feeding, moving, resting, grooming and other (including copulating, genital to genital $(\mathrm{G}-\mathrm{G})$ rubbing and alerting). When bonobos were feeding, we recorded the food type (categorized as fruits, leaves, terrestrial herbaceous vegetation (THV) and animal matter), species name and its location. When we observed the bonobos defecating, we searched for and collected the faeces if possible. Using a 1-mm mesh sieve, we sieved the faeces in river water, and then dried the contents in the sun for several days. We measured the length, width and height of each seed $(n=5)$ with a vernier caliper to the nearest $0.05 \mathrm{~mm}$. Seeds were classified as small $(<5 \mathrm{~mm})$ or large $(\geq 5 \mathrm{~mm})$ based on their longest dimension (Gross-Camp \& Kaplin 2005). We directly counted the number of the large seeds, while the numbers of the small seeds were roughly estimated as either $>1000$ or $>100$. 
We observed the E1 group over $29 \mathrm{~d}$ for a total of $254 \mathrm{~h}$. The bonobos were mostly observed in the primary forest and to a lesser extent in the swamp forest. Members of the E1 group showed symptoms of respiratory infection (e.g. coughs and snivels) for about half of December (especially 8-22 December). Movement patterns and activity budgets of the group during this time differed from those observed during other periods (Sakamaki et al. 2009). Thus we excluded the data collected during this 'disease' period (13 $\mathrm{d}$ or $122 \mathrm{~h}$ ) from the following analyses.

The mean $\pm \mathrm{SD}$ h spent in observation, distance moved, and speed of movement of the E1 group was $8.3 \pm 3.0 \mathrm{~h} \mathrm{~d}^{-1}, 2.7 \pm 1.8 \mathrm{~km} \mathrm{~d}^{-1}$, and $342 \pm 202 \mathrm{~m} \mathrm{~h}^{-1}(\mathrm{n}=16)$, respectively. The estimated range of the group during the study period was $13.5 \mathrm{~km}^{2}$ (unit grid size: $500 \mathrm{~m} \times 500 \mathrm{~m}$ ) (Figure 1). The bonobos of the E1 group spent more time feeding $(46.3 \% \pm 8.7 \%)$ than on other activities (moving: $27.2 \% \pm 9.9 \%$; resting: $19.5 \% \pm$ 10.4\%; grooming: $5.8 \% \pm 7.1 \%$; other: $1.2 \% \pm 1.5 \%(\mathrm{n}=10))$. They spent $64.9 \%$ of their feeding time on fruits, $15.6 \%$ on leaves, $18.3 \%$ on THV and $0.5 \%$ on animal matter. Among the fruits, the group members fed mainly on two species of Dialium: D. zenkeri Harms (35.3\% of fruit feeding time) and D. pachyphyllum Harms (28.1\% of fruit feeding time). The bonobos did not spit out these seeds. They also fed on Musanga cecropioides R.Br. \& Tedlie fruits (18.2\% of fruit feeding time), whose seeds they often spat out as 
wadges. They remained at a given Dialium sp. tree for long periods (mean \pm SD: $0.73 \pm$ $0.73 \mathrm{~h}$ at a single $D$. zenkeri tree $(\mathrm{n}=22)$ and $1.3 \pm 1.0 \mathrm{~h}$ at a single $D$. pachyphyllum tree $(n=3))$. They visited a small number of Dialium trees per day $(1.9 \pm 0.7 D$. zenkeri trees $(\mathrm{n}=11)$ and $1.0 \pm 0.0$ D. pachyphyllum trees $(\mathrm{n}=3))$. The number of Dialium trees utilized by the E1 group during the study period was small, at $17 \mathrm{D}$. zenkeri and $3 \mathrm{D}$. pachyphyllum trees (Figure 1).

During the observation period we collected 33 faecal samples in total. Almost all faeces $(91 \%)$ contained D. zenkeri seeds and $88 \%$ contained seeds of Musanga cecropioides, while a relatively small percentage (18\%) of faeces contained $D$. pachyphyllum seeds (Table 1). The greatest mean numbers of seeds in a single faecal sample were those of Musanga cecropioides (> 1000), Aframomum laurentii De Wild, and Ficus ottoniifolia (Miq.) Miq. (>100). The mean number of seeds per sample of $D$. zenkeri and $D$. pachyphyllum were 20 and 12 , respectively (Table 1).

In general, it is difficult to evaluate the dispersal distance of seeds carried by free-moving wild animals, and therefore many researchers estimate dispersal distance by combining the passage time of seeds observed in captive animals and radio-tracked ranging patterns of wild individuals (Hickey et al. 1999). However, if we can conduct continuous observation from feeding to defecation, and if gut passage time is known, then 
dispersal distance can be estimated by recording the locations of feeding and defecation sites, with the straight distance between the two locations being the dispersal distance. We could apply the independent bout method (Julliot 1996) to the seeds of the two species of Dialium because (1) the bonobos utilized a limited number of Dialium trees as noted above, (2) we could follow the bonobos for almost the entire day and record most feeding trees, and (3) the gut passage time of the seeds has been reported for chimpanzees, a sibling species of bonobo (Idani 1986, Lambert 1998). Their body weights are similar to each other (chimpanzees: 31.1-41.6 kg, Lambert \& Garber 1998; bonobos: 33.2-45 kg, Stumpf 2007), and this would suggest that there is little difference in the gut passage time (Lambert 1998), and therefore it seemed reasonable to substitute the passage time of the chimpanzees for that of bonobos. According to Lambert (1998), transit time (minimum retention time), mean retention time, and time of last appearance of markers for captive chimpanzees were $23.2 \mathrm{~h}, 31.5 \mathrm{~h}$, and $63.3 \mathrm{~h}$, respectively. Terakawa et al. (2009) recently reported that most of the faecal samples from the Yakushima macaques (Macaca fuscata yakui) contained seeds of diverse maternal origins from several locations. According to this, if there were several candidates for given seeds, all of which were assumed to be the mother tree.

The mean $( \pm \mathrm{SD})$ dispersal distances of $D$. zenkeri and $D$. pachyllum were $783 \pm 494$ 
m (range: $145-1886 \mathrm{~m})$ (Figure 1a) and $777 \pm 312 \mathrm{~m}$ (range: 434-1031m) (Figure 1b).

There was no difference in the dispersal distance of seeds between the two Dialium species (Mann-Whitney $U$ test, $\left.\mathrm{n}_{1}=17, \mathrm{n}_{2}=5, U=36, \mathrm{P}>0.05\right)$. Since there was no significant correlation between the dispersal distance of $D$. zenkeri and the gut retention time (Spearman's rank correlation: $r_{s}=0.142, \mathrm{P}=0.471$ ), the actual retention time is not that critical to the dispersal distances of this species. On the other hand, there was a significant positive correlation between the dispersal distance of $D$. pachyphyllum and the gut retention time $\left(r_{s}=0.692, \mathrm{P}=0.038\right)$, and therefore most seeds passing through the gut relatively quickly might be dispersed for shorter distances.

Bonobos dispersed seeds over longer distances than do other small-sized primate species inhabiting tropical forests (e.g. woolly monkey Lagothrix lagotricha, 130-450 m, Yumoto et al. (1999); red howler monkey Alouatta seniculus, 220-440 m, Julliot (1996), Yumoto et al. (1999); gibbon Hylobates muelleri $\times$ agilis, 340-430 m, McConkey \& Chivers (2007), it is noteworthy that all of these estimates were made by the independent bout method). Therefore bonobos might disperse seeds across a wider range of vegetation types (though the dispersal estimates of $D$. pachyphyllum might be biased by the retention time). Recently, however, it has been determined that seeds removed from the parent tree do not necessarily have a greater chance of survival, depending on the plant 
species and/or specific incident (Augspurger 1984, Chapman \& Chapman 1996). Thus, to draw conclusions about the adaptive significance of dispersal distances of seeds, the relationship between seed dispersal distribution and performance (e.g. germination and growth of seedlings) must be field tested. Furthermore, the present study was conducted during a brief period involving a limited number of tree species. Perhaps the ranging pattern of the bonobos and thus seed dispersal are a reflection of the food resources (Hashimoto et al. 1998) and the dispersal distance may change during other times of the year (Gross-Camp \& Kaplin 2005, Lambert \& Garber 1998). In the future, temporal changes in the dispersal should be studied.

The present study provides the first estimate of the dispersal distance of seeds by great apes, an important aspect of endozoochorous seed dispersal. The independent bout method that we employed could easily provide essential information contributing to estimations of seed dispersal patterns caused by subject animals. Since there are many study sites at which researchers can observe habituated animals, this method should be applied in other areas to study seed dispersal by the great apes.

\section{ACKNOWLEDGEMENTS}

We would like to Dr. T. Furuichi for his invitation to study at Wamba, the members of the 
Department of Ecology and the Social Behavior of Primate Research Institute, Kyoto University, and two anonymous reviewers for their constructive comments. We also would like to thank Dr. N. Mwanza, Mr. M. Mulavwa, and other staff at the Research Center for Ecology and Forestry in D. R. Congo and the field assistants for their corporation during the fieldwork. This study was financially supported by the Japan Society for the Promotion of Science Grants-in-aid for Scientific Research (No. 17255005 to Dr. T. Furuichi).

\section{LITERATURE CITED}

AUGSPURGER, C. K. 1984. Seedling survival of tropical tree species: interactions of dispersal distance, light-gaps, and pathogens. Ecology 65:1705-1712.

CHAPMAN, C. A. \& CHAPMAN, L. J. 1996. Frugivory and the fate of dispersed and non-dispersed seeds of six African tree species. Journal of Tropical Ecology $12: 491-504$.

FURUICHI, T., MULAVWA, M., YANGOZENE, K., YAMBA-YAMBA, M., MOTEMA-SALO, B., IDANI, G., IHOBE, H., HASHIMOTO, C., TASHIRO, Y. \& MWANZA, N. 2008. Relationships among fruit abundance, ranging rate, and party size and composition of bonobos at Wamba. Pp. 135-149 in Furuichi, T. \& Thomson, 
J. (eds.). The Bonobos: behavior, ecology, and conservation. Springer, New York.

GROSS-CAMP, N. \& KAPLIN, B. A. 2005. Chimpanzee (Pan troglodytes) seed dispersal in an afromontane forest: microhabitat influences on the post dispersal fate of large seeds. Biotropica 37:641-649.

HASHIMOTO, C., TASHIRO, Y., KIMURA, D., ENOMOTO, T., INGMANSON, E. J., IDANI, G. \& FURUICHI, T. 1998. Habitat use and ranging of wild bonobos (Pan paniscus) at Wamba. International Journal of Primatology 19:1045-1060.

HICKEY, J. R., FLYNN, R. W., BUSKIRK, S. W., GEROW, K. G. \& WILLSON, M. F. 1999. An evaluation of a mammalian predator, Martes americana, as a disperser of seeds. Oikos 87:499-508.

IDANI, G. 1986. Seed dispersal by pygmy chimpanzees (Pan paniscus) - a preliminary report. Primates 27:441-447.

JULLIOT, C. 1996. Seed dispersal by red howling monkeys (Alouatta seniculus) in the tropical rain forest of French Guiana. International Journal of Primatology $17: 239-258$.

KANO, T. \& MULAVWA, M. 1984. Feeding ecology of the pygmy chimpanzees (Pan paniscus) of Wamba. Pp. 233-274 in Sussman, R. L. (ed.) The pygmy chimpanzee: evolutionary biology and behaviour. Plenum Press, New York. 
LAMBERT, J. E. 1998. Primate digestion: interactions among anatomy, physiology, and feeding ecology. Evolutionary Anthropology 7:8-20.

LAMBERT, J. E. 1999. Seed handling in chimpanzees (Pan troglodytes) and redtail monkeys (Cercopithecus ascanius): implications for understanding hominoid and cercopithecine fruit-processing strategies and seed dispersal. American Journal of Physical Anthropology 109:365-386.

LAMBERT, J. E. \& GARBER, P. A. 1998. Evolutionary and ecological implications of primate seed dispersal. American Journal of Primatology 45:9-28.

MCCONKEY, K. R. \& CHIVERS, D. J. 2007. Influence of gibbon ranging patterns on seed dispersal distance and deposition site in a Bornean forest. Journal of Tropical Ecology 23:269-275.

POULSEN, J. R., CLARK, C. J. \& SMITH, T. B. 2001. Seed dispersal by a diurnal primate community in the Dja Reserve, Cameroon. Journal of Tropical Ecology $17: 787-808$.

ROGERS, M. E., VOYSEY, B. C., MCDONALD, K. E., PARNELL, R. J. \& TUTIN, C. E. G. 1998. Lowland gorillas and seed dispersal: the importance of nest sites. American Journal of Primatology 45:45-68.

SAKAMAKI, T., MULAVWA, M. \& FURUICHI, T. 2009. Epidemics of a flu-like 
disease in wild bonobos (Pan paniscus) at Wamba, the Luo Scientific Reserve,

Democratic Republic of Congo. Pan Africa News 16:1-4.

STUMPF, R. 2007. Chimpanzees and bonobos: diversity within and between species. Pp.

321-344 in Campbell, C. J., Fuentes, A., MacKinnon, K. C., Panger, M. \& Bearder, S.

K. (ed.). Primates in perspective. Oxford University Press, Oxford.

TERAKAWA, M., ISAGI, Y., MATSUI, K. \& YUMOTO, T. 2009. Microsatellite

analysis of the maternal origin of Myrica rubra seeds in the feces of Japanese

macaques. Ecological Research 24:663-670.

VOYSEY, B. C., MCDONALD, K. E., ROGERS, M. E., TUTIN, C. E. G. \& PARNELL, R. J. 1999a. Gorillas and seed dispersal in the Lope Reserve, Gabon. I: gorilla acquisition by trees. Journal of Tropical Ecology 15:23-38.

VOYSEY, B. C., MCDONALD, K. E., ROGERS, M. E., TUTIN, C. E. G. \& PARNELL, R. J. 1999b. Gorillas and seed dispersal in the Lope Reserve, Gabon. II: survival and growth of seedlings. Journal of Tropical Ecology 15:39-60.

WRANGHAM, R. W., CHAPMAN, C. A. \& CHAPMAN, L. J. 1994. Seed dispersal by forest chimpanzees in Uganda. Journal of Tropical Ecology 10:355-368.

YUMOTO, T., KIMURA, K. \& NISHIMURA, A. 1999. Estimation of the retention times and distances of seed dispersed by two monkey species, Alouatta seniculus and 
Lagothrix lagotricha, in a Colombian forest. Ecological Research 14:179-191. 
Table 1. Plant species, seed appearance, and number of seeds within the faeces $(n=33)$ of the bonobos. Values in parentheses are percentage of appearance.

\begin{tabular}{|c|c|c|c|}
\hline Species & \multicolumn{2}{|c|}{$\begin{array}{l}\text { Number of } \\
\text { appearance }\end{array}$} & $\frac{\text { Seed number }}{\text { Mean } \pm \text { SD }}$ \\
\hline \multicolumn{4}{|l|}{ Casalpiniaceae } \\
\hline Dialium zenkeri & 30 & (90.9) & $19.7 \pm 28.2$ \\
\hline Dialium pachyphyllum & 6 & $(18.2)$ & $12.5 \pm 8.4$ \\
\hline \multicolumn{4}{|l|}{ Moraceae } \\
\hline Musanga cecropioides & 29 & $(87.9)$ & $>1000$ \\
\hline Ficus ottoniifolia (Miq.) Miq. & 2 & $(6.1)$ & $>100$ \\
\hline \multicolumn{4}{|l|}{ Marantaceae } \\
\hline Megaphrynium macrostachyum (Benth.) Milne-Redhead. & 14 & $(42.4)$ & $6.5 \pm 5.8$ \\
\hline \multicolumn{4}{|l|}{ Zingiberaceae } \\
\hline Aframomum laurentii De Wild & 6 & $(18.2)$ & $>100$ \\
\hline \multicolumn{4}{|l|}{ Tiliaceae } \\
\hline Grewia pinnatifida Mast. & 3 & $(9.1)$ & $3.7 \pm 3.8$ \\
\hline \multicolumn{4}{|l|}{ Apocynaceae } \\
\hline Landolphia owariensis P.Beauv. & 3 & $(9.1)$ & $1.7 \pm 0.6$ \\
\hline unidentified A & 2 & $(6.1)$ & $>100$ \\
\hline unidentified B & 1 & (3.0) & $1.5 \pm 0.7$ \\
\hline unidentified $\mathrm{C}$ & 1 & $(3.0)$ & 1.0 \\
\hline
\end{tabular}




\section{FIGURE LEGEND}

Figure 1. Range of the E1 group during the study period (from the end of November 2008 to the beginning of January 2009, excluding the 'disease period') and the estimated dispersal distances of Dialium zenkeri (a) and Dialium pachyphyllum (b). •: location of $D$. zenkeri trees, $\circ$ : location of $D$. pachyphyllum trees, $\square$ : defecation sites. Arrows show directions of dispersal. If we obtained several distances, we showed only the longest ones. Note that number of arrows is smaller than that of faecal samples for which we estimated the distance because several faecal samples were defecated at same places. Grid size is $500 \mathrm{~m} \times 500 \mathrm{~m}$. 
a)

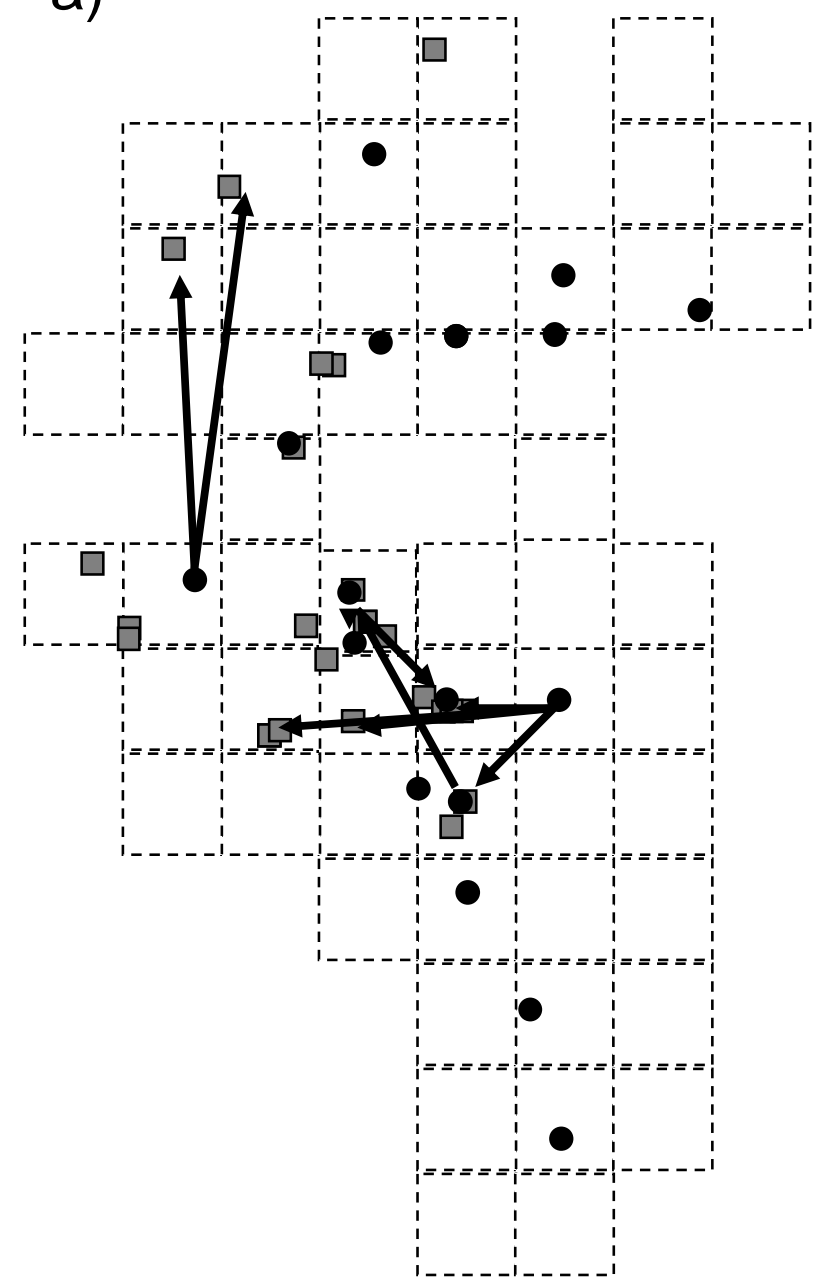

- Dialium zenkeri tree $(\mathrm{n}=17)$

$\square \quad$ Defecation sites

:-: Home range $(500 \mathrm{~m} \times 500 \mathrm{~m})$

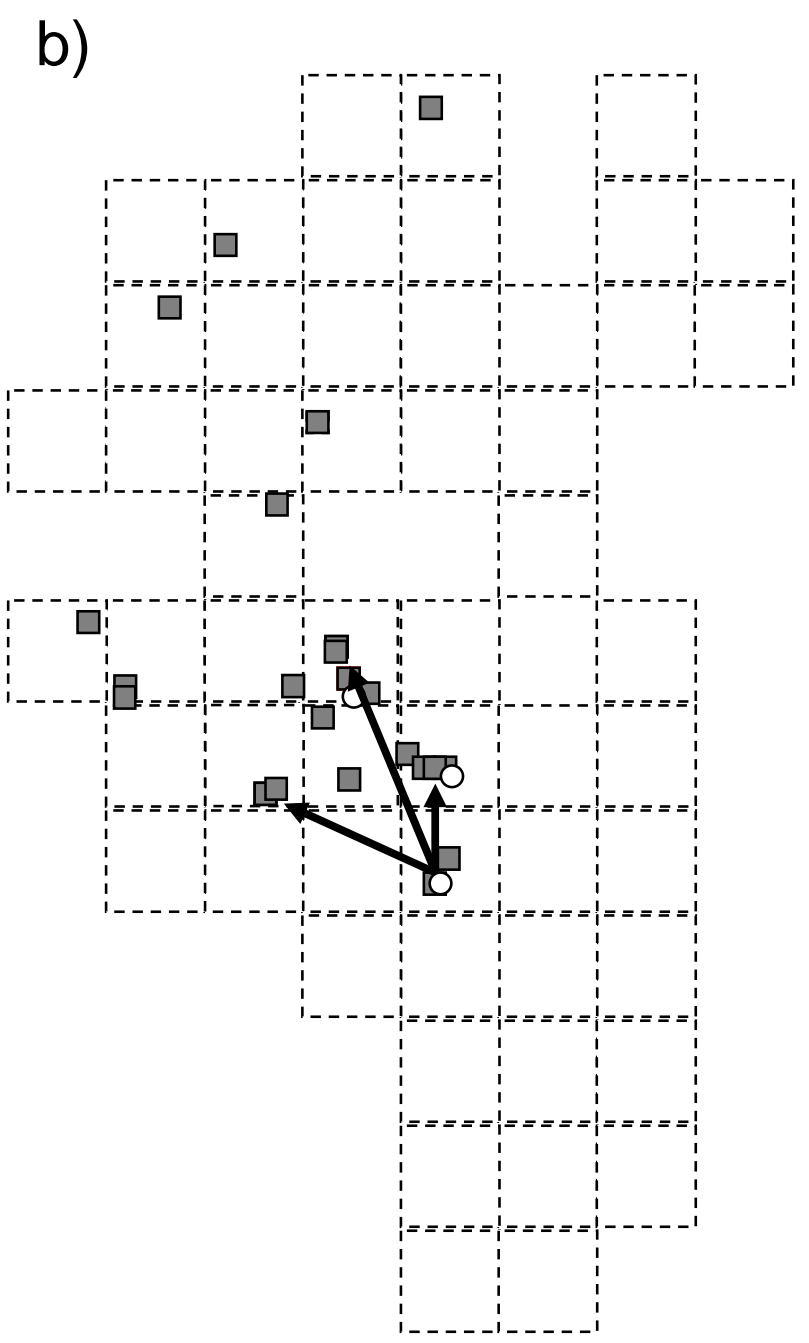

Dialium pachyphyllum tree $(\mathrm{n}=3)$ 